\title{
Shyness and boldness in greater rheas Rhea americana Linnaeus (Rheiformes, Rheidae): the effects of antipredator training on the personality of the birds
}

\author{
Cristiano S. de Azevedo \& Robert J. Young
}

\begin{abstract}
Pós-graduação em Zoologia de Vertebrados, Conservation, Ecology and Animal Behaviour Group, Pontifícia Universidade Católica de Minas Gerais. Avenida Dom José Gaspar 500, Prédio 41, Coração Eucarístico, 30535-610 Belo Horizonte, Minas Gerais, Brasil. E-mail: cristianoroxette@yahoo.com; robyoung@pucminas.br
\end{abstract}

\begin{abstract}
The shy-bold continuum is an axis of behavioural variation for some species, but the consequences of shyness and boldness in antipredatory behaviour is unknown. Bold animals have the tendency to be predated first after release in comparison to shy animals, who naturally avoid the predators. Antipredatory training has been used to enhance the defence behaviours of naive animals by various researchers around the world. For greater rheas, Rhea americana (Linnaeus, 1758), this kind of study is pioneer. In this study we have investigated if there are relationships between personality and performance of greater rheas in antipredatory training. We also investigated if the training procedures influenced the behaviour of the birds when presented to novel objects. Fifteen zoo-borne greater rheas were studied and 16 personality tests were run, being eight before the application of antipredator training, and eight after the training. We presented to the birds four novel objects (ball, box, bag and person) and recorded their behaviour and the distance of the birds in relation to the objects. Results showed that the birds behave boldly before training and shyly after it. The antipredator training modified significantly the behaviour of the rheas, making them more careful about novel situations. Personalities affected the behaviour of the birds during antipredator training. The study of the animal personalities can be an useful tool in reintroduction programs since it helps to choose the animals with the highest chance of survival to reintroduce.
\end{abstract}

KEY WORDS. Aves; naive birds; novel objects; personality test; reintroduction.

RESUMO. Timidez e coragem em emas Rhea americana Linnaeus (Rheiformes, Rheidae): os efeitos do treinamento anti-predação na personalidade das aves. O contínuo timidez-coragem é um eixo de variação comportamental para algumas espécies, mas as conseqüiências da timidez e coragem no comportamento antipredação não são conhecidas. Animais corajosos tendem a ser predados primeiramente após a reintrodução em comparação com os animais tímidos, que naturalmente evitam os predadores. $O$ treinamento anti-predação tem sido usado para aumentar os comportamentos defensivos de animais nascidos em cativeiro por vários pesquisadores ao redor do mundo. Para emas, Rhea americana (Linnaeus, 1758), este tipo de estudo é pioneiro. Neste estudo, foi investigado se existe relação entre a personalidade e a performance das emas no treinamento anti-predação. Também foi investigado se o treinamento influencia o comportamento das aves quando apresentadas a novos objetos. Foram estudadas 15 emas nascidas em cativeiro, através de 16 testes de personalidade, sendo oito antes da aplicação do treinamento anti-predação e oito após sua aplicação. Foram apresentados às emas quatro novos objetos (bola, caixa, saco e pessoa) e anotados os comportamentos exibidos e a distância das aves em relação aos objetos. O treinamento anti-predação modificou significativamente o comportamento das emas, tornando-as mais cuidadosas em relação à novas situações. A personalidade afetou o comportamento das aves durante o treinamento anti-predação. $O$ estudo da personalidade dos animais pode ser uma ferramenta útil em programas de reintrodução, uma vez que ajuda na escolha de qual animal tem maior chance de sobrevivência ao ser solto. PALAVRAS CHAVE. Aves cativas; objetos novos; reintrodução; teste de personalidade.

Behavioural differences attributed to personality traits have been demonstrated to many species, like octopus (MATHER \& ANDERsson 1993), fishes (Wilson et al. 1993, Coleman \& WiLson 1998), birds (GreEnberg 1989, Verbeek et al. 1999) and mam- mals (Lowe \& Bradshaw 2001, Svartberg 2002, Svartberg \& FORKMAN 2002). These differences are classified in a shy-bold continuum, defined as the tendency of an animal to approach to an object and situation not familiar to it and to take risks 
(KAGAN et al. 1988, WiLSon et al. 1994). In general, shy individuals react to unknown objects or situations becoming quiet and vigilant; bold individuals act normally or become active, exploring the new situation (WILSON et al. 1993).

Animal personalities can be decisive in the capacity of a captive animal to survive after the release into the wild. BREMNERHARRISON et al. (2004), studying swift-foxes Vulpes velox (Say, 1823) in the United States, discovered that the bold animals presented mortality rates significantly higher than the shy ones, and that the bold individuals die faster after the release if compared to the shy individuals.

According to Coleman \& WILsON (1998), individual differences which are adaptative in the context of predator avoidance may be or not adaptative in other contexts, like in intraspecific social interactions. Each important situation that affect the survival and the reproduction potentially requires a different adaptative response, favoured by natural selection; therefore, it would be more adaptative to a shy-bold continuum exist to some situations but not to others. If these responses are naturally selected, it seems that this continuum are partially inheritable. In fact, today, this characteristic seems to be unquestionable (WILSON et al. 1994).

With the genetic component of the shy-bold continuum being inherited from father to sons, personality studies may be of great importance for the selection of animals more inclined to learn about predators, who can become models to naive conspecifics (SNEDDON 2003). Bold individuals who learn faster can be candidates to models for the social transmission of their abilities, meanwhile, training shy individuals are also important, since in the case of predator recognition, bold are not an advantageous skill. The ideal situation, therefore, would be the reproduction of individuals with a great capacity of learning and not so bold, occupying not the extremes of the shy-bold continuum but the intermediary positions that allow the right responses in front of the predators. Once the amount of money involved in animal reintroduction projects are enormous (KLEIMAN 1996), this kind of investigation would avoid unnecessary expenditure with the training of animals whose the chance of survival after the release into the wild are low.

Greater rhea Rhea americana Linnaeus, 1857 (Rheiformes, Rheidae, Aves) is the largest South American bird. It lives in the open fields and cerrado and open-grass regions of Brazil, Argentina, Paraguay, Uruguay and southern Bolivia (DEL Hoyo et al. 1992). Despite the species be classified in the category of lowerrisk by IUCN (2004), natural populations are declining, being the intensive hunt, habitat loss, egg destruction by agricultural machinery, burnings and predation, the main reasons for that (DANI 1993). Predators of greater rhea are bush dog, Speothos venaticus Lund, 1842; maned-wolf, Chrysocyon brachyurus Illiger, 1811; jaguar, Panthera onca Linnaeus, 1758; feral dogs, Canis familiaris Linnaeus, 1758; tegu lizard, Tupinambis teguixin Linnaeus, 1758; and some birds of prey (SICK 1997).

In the Brazilian State of Minas Gerais, the species is clas- sified as threatened (MACHADO et al. 1998). Reintroduction efforts have been made to contour this situation, but with no success due mainly to the predation of the individuals (Ângela Faggioli, BH Zoo Biologist, pers. comm.).

Our goal in this study was to evaluate personality traits of captive-born greater rheas and to correlate the personalities of the birds with the responses showed during antipredator training session.

\section{MATERIAL AND METHODS}

\section{Animals, housing and maintenance}

Fifteen greater rheas (eight males and seven females), all bred at Belo Horizonte Zoo (BH Zoo), were studied. Rheas were caught and handled regularly prior to the experiments.

Eight birds were housed in enclosures $15 \mathrm{~m}$ long and 15 $\mathrm{m}$ wide (four birds per enclosure - trained groups) and seven birds were housed in a enclosure $28 \mathrm{~m}$ length and $16 \mathrm{~m}$ wide (untrained group). All rheas received food and water ad libitum and were marked (plastic coloured leg. bands and leg. tattoos) for identification.

\section{Antipredator training}

Two groups were trained to avoid predators. Antipredator training sessions were based on the methodology of GRIFFIN et al. (2001). We paired two stimuli: a predator model with an aversive stimulus (a simulation of a capture procedure). We trained the rheas in a test yard; this wire-fenced arena was screened with strip of opaque black plastic to isolate the birds visually from their surroundings. A window in one of the long sides of the enclosure allowed the birds to see the predator model, which passed in a corridor adjoining the fence. Just after the predator model appeared in the window, a man carrying a net entered the enclosure and simulated a capture procedure (aversive experience). In the trained group, the appearance of the stimulus; thus reliably predicted the onset of the capture event. Each animal received 15 training sessions, separated equally being the taxidermized jaguar, a chair (control stimulus) and a live dog, from June to September 2003.

The control group was not submitted to antipredator training and the behavioural responses of this group allowed us to evaluate the effectiveness of the training procedures in the elicitation of the correct antipredator behaviours.

\section{Experimental protocol}

Personality tests were run before and after antipredator training sessions, for both trained and untrained groups. Tests consisted in the presentation of four novel objects to the rheas and the evaluation of their behavioural responses.

In each enclosure we marked two squares, one inside of the other (Fig. 1), which helped us to evaluate the distance of the birds in relation of the novel object, which was put in the centre of the squares. The marks consisted in wood sticks stringed on the ground. If the bird entered on the bigger square (square two), it would be at $2.60 \mathrm{~m}$ distant of the object; if it 


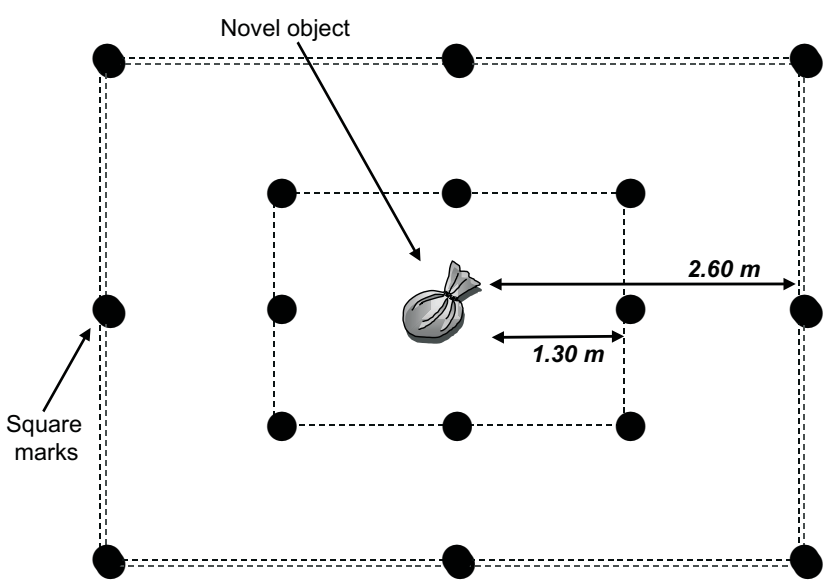

Figure 1. Squares built in each enclosure to evaluate the distances of the rheas in relation to the novel objects; if the bird entered the larger square, it would be approximately at $2.60 \mathrm{~m}$ of the object; if the bird entered the lesser square, it would be approximately at $1.30 \mathrm{~m}$ of the object.

entered on the smaller square (square one), it would be at 1.30 $m$ distant of the object.

Four novel objects were used: a ball, a bag, a box and a person; none of this objects had been presented to the birds before the tests (excluding the person - birds were managed regularly by their zoo keepers). The sequence of object presentation was: ball, bag, box and person. Each object was presented to the birds two times before antipredator training and two times after the end of the training sessions, totalling 16 personality tests (eight tests before training, in February 2003, and eight tests after training, in July 2003).

\section{Data collection and statistical analysis}

We collected data about the behaviours displayed during the tests and the distance of the birds in relation to the novel objects. Data were collected using scan sampling with instantaneous recording of behaviour every minute. If one bird entered the squares and interact with the object, its number was recorded. Each test lasted 60 minutes and started right after the arrangement of the object inside the squares; tests were run in the morning, being one test per day.

Behaviours displayed by the rheas during the tests were divided into three personality categories: bold (this category comprises the behaviours walking, foraging, inactive, pecking at the object and watching the object), shy (behaviours pacing and alert) and fear (behaviour escaping from the object and not visible). The number of registers of each behaviour was counted and used in the calculation of the boldness scores, according to BREMNER-HARRISON et al. (2004): the total number of fear behaviours was multiplied by zero; the total number of shy behaviours was multiplied by one; and the total number of bold behaviours was multiplied by two. For each group, the totals of the multiplication were summed and the numbers achieved were the boldness score values - the bigger the value, the bigger the boldness of the group (Tab. I).

Results found during the personality tests were compared to the results found during the antipredator training sessions. Cluster analysis grouped the rheas according to the similarities of the behaviours expressed during antipredator training and was also used in the comparisons with the boldness scores.

Friedman's ANOVA non-parametrical tests were used to evaluate if the differences in the behaviours between the three groups before and after the training sessions were statistically significant. For all statistical analysis, the confidence level was

Table I. Example of the calculation of the boldness score (BREMER-HARRISON 2004). Trained-groups one and two were submitted to prior antipredator training sessions. Higher the boldness score, higher the boldness of the group. Group 1

\begin{tabular}{|c|c|c|c|}
\hline Number of registers of bold behaviours & $=30$ & & \\
\hline Number of registers of shy behaviours & $=10$ & & \\
\hline Number of registers of fear behaviours & $=8$ & & \\
\hline \multicolumn{4}{|l|}{ Group 2} \\
\hline Number of registers of bold behaviours & $=37$ & & \\
\hline Number of registers of shy behaviours & $=12$ & & \\
\hline Number of registers of fear behaviours & $=10$ & & \\
\hline \multicolumn{4}{|l|}{ Boldness score calculation } \\
\hline \multicolumn{2}{|l|}{ Group 1} & \multicolumn{2}{|c|}{ Group 2} \\
\hline Bold & $2 \times 30=60$ & Bold & $2 \times 37=74$ \\
\hline Shy & $1 \times 10=10$ & Shy & $1 \times 12=12$ \\
\hline Fear & $0 \times 8=0$ & Fear & $0 \times 10=0$ \\
\hline Total & 70 & Total & 86 \\
\hline
\end{tabular}


95\% $(\alpha=0.05)$. All statistical tests were run using MINITAB Statistical Software v.12.

\section{RESULTS}

The behaviours escaping from the object, pecking at the object and foraging were excluded from statistical analysis because they were not recorded or seldom recorded. The mean number of behaviours is shown on table II, for each treatment and each object.

Results showed that the groups responded differently to the novel objects; rheas of trained-group one behave shyly before and after the training sessions; trained-group two behave boldly before and shyly after training; control group behave boldly before and after the training sessions, except when the person was the object (rheas behave shyly). For the box, rheas of control group behave boldly before and shyly after the training sessions (Tab. II).

Control group did not show any statistical difference in the behaviours displayed during personality tests before and after antipredator training (Tab. III). Only for the rheas of the trained groups one and two the responses were statistically different. For both groups, differences were found in the categories shy and bold; Tukey test showed that bold behaviours occurred most in the treatment one (before antipredator training) and shy behaviours occurred most in the treatment two (after antipredator training).

Boldness scores, calculated for all groups, are shown in table IV. Results showed that the three groups behave boldly before the antipredator training and shyly after the training sessions.

Rheas of group one entered in the square two $(2.60 \mathrm{~m}$ from the novel object) more times than in square one $(1.30 \mathrm{~m}$ from the novel object) (34 times for square two; 11 times for square one), before antipredator training (Tab. V). Rheas of group two showed the same pattern: entered more in square two than in square one (Tab. V). Only control group entered more in square one than in square two (29 times in square one; 20 times in square two) before antipredator training (Tab. V). After the training, all groups entered more in square two than in square one. Most of the place recordings occurred for distances higher than $2.60 \mathrm{~m}$ from the novel object, for the three groups (Tab. V).

Table II. Mean number of registers ( standard error of the behaviours displayed by the greater rheas submitted to personality tests at BH Zoo, analysed by treatments: (1) before antipredator training, (2) after antipredator training. (-) Behaviours not expressed.

\begin{tabular}{|c|c|c|c|c|c|}
\hline \multirow{2}{*}{ Rhea } & \multirow{2}{*}{ Treatment } & \multicolumn{4}{|c|}{ Behaviours } \\
\hline & & Object & Fear & Shy & Bold \\
\hline \multirow[t]{8}{*}{ Group 1} & 1 & Ball & $5.50 \pm 0.5$ & $110.00 \pm 4.0$ & $55.00 \pm 5.00$ \\
\hline & & Bag & $4.50 \pm 3.5$ & $99.50 \pm 18.5$ & $68.00 \pm 3.00$ \\
\hline & & Box & $2.50 \pm 2.5$ & $122.50 \pm 1.5$ & $71.50 \pm 14.50$ \\
\hline & & Person & - & $130.50 \pm 27.5$ & $62.00 \pm 10.00$ \\
\hline & 2 & Ball & $4.00 \pm 4.0$ & $140.50 \pm 11.5$ & $45.00 \pm 34.00$ \\
\hline & & Bag & - & $154.00 \pm 0.0$ & $47.00 \pm 28.00$ \\
\hline & & Box & $1.50 \pm 0.5$ & $177.50 \pm 3.5$ & $37.00 \pm 5.00$ \\
\hline & & Person & - & $158.50 \pm 11.5$ & $21.00 \pm 7.00$ \\
\hline \multirow[t]{8}{*}{ Group 2} & 1 & Ball & $17.50 \pm 2.5$ & $53.00 \pm 6.0$ & $91.50 \pm 12.50$ \\
\hline & & Bag & $17.00 \pm 10.0$ & $46.00 \pm 13.0$ & $116.00 \pm 18.00$ \\
\hline & & Box & $32.00 \pm 20.0$ & $46.50 \pm 0.5$ & $105.00 \pm 23.00$ \\
\hline & & Person & $0.50 \pm 0.5$ & $19.50 \pm 3.5$ & $131.50 \pm 8.50$ \\
\hline & 2 & Ball & $15.00 \pm 5.0$ & $116.00 \pm 31.0$ & $56.00 \pm 17.00$ \\
\hline & & Bag & $4.00 \pm 2.0$ & $125.50 \pm 6.5$ & $48.00 \pm 4.00$ \\
\hline & & Box & $6.00 \pm 1.0$ & $176.00 \pm 9.0$ & $26.50 \pm 5.50$ \\
\hline & & Person & - & $199.50 \pm 14.5$ & $15.50 \pm 5.50$ \\
\hline \multirow[t]{8}{*}{ Control group } & 1 & Ball & - & $61.00 \pm 40.0$ & $221.00 \pm 57.00$ \\
\hline & & Bag & $0.50 \pm 0.5$ & $109.00 \pm 63.0$ & $254.50 \pm 38.50$ \\
\hline & & Box & $1.00 \pm 1.0$ & $56.50 \pm 4.5$ & $256.00 \pm 15.00$ \\
\hline & & Person & $1.00 \pm 1.0$ & $174.00 \pm 14.0$ & $164.00 \pm 2.00$ \\
\hline & 2 & Ball & $11.00 \pm 4.0$ & $106.50 \pm 44.5$ & $167.50 \pm 64.50$ \\
\hline & & Bag & $11.50 \pm 0.5$ & $114.50 \pm 32.5$ & $180.00 \pm 79.00$ \\
\hline & & Box & $8.50 \pm 2.5$ & $191.00 \pm 27.0$ & $131.50 \pm 31.50$ \\
\hline & & Person & - & $153.00 \pm 34.0$ & $144.00 \pm 55.00$ \\
\hline
\end{tabular}


Table III. Friedman results for the behaviours of greater rheas submitted to the personality tests at BH Zoo. Treatments: (1) before antipredator training, (2) after antipredator training, $\mathrm{N} 1=161, \mathrm{df}=1$.

\begin{tabular}{lcccc}
\hline \multirow{2}{*}{ Rhea group } & Treatment & \multicolumn{3}{c}{ Friedman $(\mathrm{p}$-value $)$} \\
\cline { 3 - 5 } & & $1 \times 2$ & Fear & Bold \\
\hline Group 1 & $1 \times 2$ & $2.59(0.21)$ & $48.10(<0.001)$ & $9.37(<0.01)$ \\
Group 2 & $1 \times 2$ & $3.64(0.06)$ & $43.83(<0.001)$ & $6.36(<0.01)$ \\
Control group & $1 \times 2)$ & $3.43(0.06)$ & $0.06(0.79)$ \\
\hline
\end{tabular}

Table IV. Boldness scores calculated according to BrEMNER-HERRISON (2004) for the rheas submitted to the personality tests at BH Zoo. Treatments: (1) before antipredator training, (1) after antipredator training.

\begin{tabular}{lccccc}
\hline Rhea group & Treatment & Fear & Shy & Bold & Boldness score \\
\hline Group 1 & 1 & $0 \times 25=0$ & $1 \times 925=925$ & $2 \times 513=1026$ & 1951 \\
& 2 & $0 \times 11=0$ & $1 \times 1261=1261$ & $2 \times 300=600$ & 1861 \\
Group 2 & 1 & $0 \times 134=0$ & $1 \times 330=330$ & $2 \times 888=1776$ & 2106 \\
& 2 & $0 \times 50=0$ & $1 \times 1234=1234$ & $2 \times 292=584$ & 1818 \\
Control group & 1 & $0 \times 5=0$ & $1 \times 801=801$ & $2 \times 1809=3618$ & 4419 \\
& 2 & $0 \times 62=0$ & $1 \times 1130=1130$ & $2 \times 1246=2492$ & 3622 \\
\hline
\end{tabular}

The numbers after the multiplication signals corresponds to the number of registers of the behaviours in each personality categories (fear, shy and bold).

Table V. Distances of the rhea groups in relation to the novel objects during personality tests at BH Zoo. Treatments: (1) before antipredator training, (1) after antipredator training.

\begin{tabular}{lcrrr}
\hline \multirow{2}{*}{ Rhea group } & Treatment & \multicolumn{3}{c}{ Distances to the objects $(\mathrm{m})$} \\
\cline { 3 - 5 } & & 1.30 & 2.60 & $>2.60$ \\
\hline Group 1 & 1 & 11 & 34 & 1875 \\
& 2 & 4 & 7 & 1909 \\
Group 2 & 1 & 41 & 45 & 1834 \\
& 2 & 3 & 9 & 1908 \\
Control group & 1 & 29 & 20 & 3311 \\
& 2 & 7 & 18 & 3097 \\
\hline
\end{tabular}

Results for each bird individually are showed on table VI. Rhea six was the bird who approached the objects more times. Rheas four and fifteen approached less times the novel objects. Most of the birds approached the novel objects more times during treatment one (before antipredator training sessions) than during treatment two (after antipredator training sessions).

During antipredator training, rheas of group one behave boldly in relation of the rheas of group two, which behave shyly (Tab. VII) when presented to the jaguar model. When tested with the chair, both groups behave calmly. With the live $\mathrm{dog}$, groups differed in their behavioural responses; group one behave calmly and group two behave vigilantly). Analysing the behaviours of each bird individually, we can note that the responses to the models differed, with birds displaying bold behaviours (ex.: rhea three) and birds displaying shy behaviours (ex.: rhea eight).

Cluster analysis resulted in two major groups: one composed by rheas one and five and the other composed by rheas three and seven. Rheas one and five behave shyly and rheas three and seven behave boldly. The similarity between the behaviours displayed by rheas one and five was 78\% approximately and between rheas three and seven was $80 \%$ approximately. The bird that behaves more different was rhea eight; this bird displayed shy and fear behaviours with the two predator models (mainly the behaviour running straight) (Fig. 2).

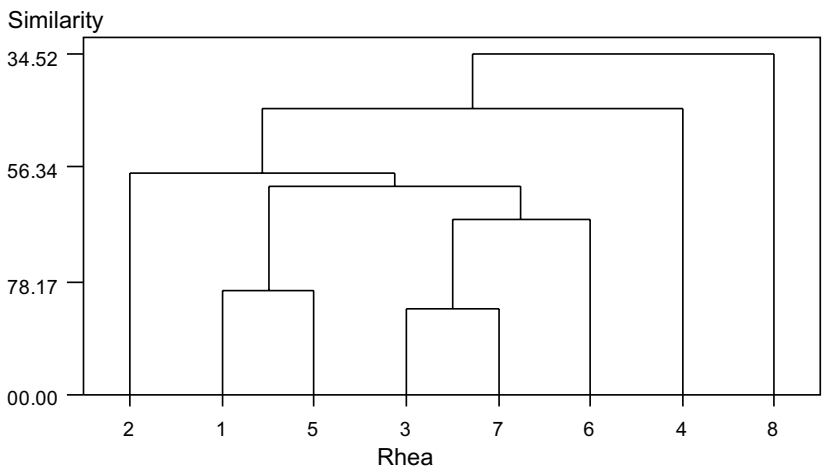

Figure 2. Cluster analysis of the behavioural responses of the greater rheas submitted to antipredator training at $\mathrm{BH}$ Zoo. Distance measure: Euclidean, Linkage method: Single, MINITAB Statistical Software v. 12. 
Table VI. Distances of each rhea in relation to the novel objects during personality tests. Treatments: (1) before antipredator training, (1) after antipredator training.

\begin{tabular}{|c|c|c|c|c|}
\hline \multirow{2}{*}{ Rhea } & \multirow{2}{*}{ Treatment } & \multicolumn{3}{|c|}{ Distances to the objects $(\mathrm{m})$} \\
\hline & & 1.30 & 2.60 & $>2.60$ \\
\hline \multirow[t]{2}{*}{1} & 1 & - & - & 480 \\
\hline & 2 & 2 & 1 & 477 \\
\hline \multirow[t]{2}{*}{2} & 1 & 8 & 9 & 463 \\
\hline & 2 & 1 & 1 & 478 \\
\hline \multirow[t]{2}{*}{3} & 1 & 4 & 12 & 464 \\
\hline & 2 & - & - & 480 \\
\hline \multirow[t]{2}{*}{4} & 1 & 1 & - & 479 \\
\hline & 2 & - & 1 & 479 \\
\hline \multirow[t]{2}{*}{5} & 1 & 1 & 5 & 474 \\
\hline & 2 & - & - & 480 \\
\hline \multirow[t]{2}{*}{6} & 1 & 33 & 31 & 416 \\
\hline & 2 & - & 7 & 473 \\
\hline \multirow[t]{2}{*}{7} & 1 & 5 & 17 & 458 \\
\hline & 2 & 4 & 6 & 470 \\
\hline \multirow[t]{2}{*}{8} & 1 & - & 5 & 475 \\
\hline & 2 & - & - & 480 \\
\hline \multirow[t]{2}{*}{9} & 1 & 8 & 6 & 466 \\
\hline & 2 & - & 1 & 479 \\
\hline \multirow[t]{2}{*}{10} & 1 & 10 & 5 & 465 \\
\hline & 2 & 4 & 12 & 464 \\
\hline \multirow[t]{2}{*}{11} & 1 & 2 & 4 & 474 \\
\hline & 2 & - & - & 480 \\
\hline \multirow[t]{2}{*}{12} & 1 & 1 & 3 & 476 \\
\hline & 2 & - & 1 & 479 \\
\hline \multirow[t]{2}{*}{13} & 1 & 4 & - & 476 \\
\hline & 2 & 2 & 2 & 238 \\
\hline \multirow[t]{2}{*}{14} & 1 & 4 & - & 476 \\
\hline & 2 & 1 & 2 & 477 \\
\hline \multirow[t]{2}{*}{15} & 1 & - & 2 & 478 \\
\hline & 2 & - & - & 480 \\
\hline
\end{tabular}

$(-)$ No registers during the personality tests.

\section{DISCUSSION}

Rheas' personalities affected the behavioural responses during antipredator training since each bird responded differently during the sessions. Antipredator training modified the responses obtained during personality tests, since birds that initially behave boldly became shy after the sessions.

Boldness scores, calculated according to BREMNER-HARRISON et al. (2004), showed that, before antipredator training sessions, rheas were bolder than after. These results were more evident for rheas belonging to trained-group two, and less evident for trained- group one (which behave shyly before and after antipredator training), although this group displayed shy behaviours more intensively after the training sessions. Untrained-group behave boldly in both treatments, with three of the four objects used (only with the person these group behave shyly), confirming that the antipredator training changed the bold levels of the birds, making them more careful to unfamiliar objects.

Bold and shy behaviours of both trained groups differed statistically between the two treatments (before and after antipredator training). This result was not observed for the untrained-group, also confirming the capacity of the training in modify the behaviours of the rheas, that learned to avoid and fear novel situations.

Analysing the number of times that the individuals approached the objects, we realised that rhea six (trained-group two) was more bold than the others, entering the squares 64 times. We found a correlation between the behaviour displayed during personality tests and antipredator training for this bird; it behave calmly in most training sessions (only with the jaguar model this bird displayed vigilance behaviours, such as alert).

Boldness scores revealed an antagonism between the behavioural responses showed during antipredator training and personality assessments. According to this index, trained-group one showed more shy than trained-group two, avoiding to approach the novel objects; meanwhile, during antipredator training, it was trained-group one who behave boldly. In the calculation of the boldness score proposed by BREMNER-HARRISON et al. (2004), fear behaviours are multiplied by zero, while bold behaviours are multiplied by two. Maybe these different weights given to the behaviour categories are responsible for this kind of antagonism. Other methods of boldness calculations are found in the literature (WILson et al. 1993, COLEMAN \& WILSON 1998, Svartberg 2002, Svartberg \& Forkman 2002, Sneddon 2003) and, for best standardised the scores, a comparison of the results found using different methods is suggested.

The cluster analysis separated two similar groups with two rheas each: one with rheas one and five (shy) and other with rheas three and seven (bold). The use of these four individuals as models for naive birds might be adequate only if they were mixed, guaranteeing the necessary variation for adaptability (WILson et al. 1994), since boldness is not a virtue in the case of antipredator adaptations. The differences showed by individuals within a single population are assumed to be nonadaptative around an adaptative mean (COLEMAN \& WiLSON 1998). It is now becoming clear that this variation can itself be adaptative, since the animals that lives socially can speed their learning processes imitating conspecifics, adapting faster to new situations (KelLey et al. 2003).

GALEF (1988) showed that the behaviour of some animals can be modified as a result of observing the responses of conspecifics to a stimulus and the social transmission of predator avoidance amplifies the effects of an initial training intervention (CURIO 1988, Suboski et al. 1990) by causing adaptative re- 
Table VII. Mean ( standard errors of the behaviours expressed by the rheas during antipredator training sessions, analysed by treatments (results are given for groups and each bird individually). Treatments: (1) jaguar, (2) chair, (3) dog.

\begin{tabular}{|c|c|c|c|c|c|c|c|}
\hline \multirow{3}{*}{ Rhea } & \multirow{3}{*}{ Treatment } & \multicolumn{6}{|c|}{ Behaviours } \\
\hline & & \multirow{2}{*}{ Alert } & \multirow{2}{*}{ Walking } & \multirow{2}{*}{ Inactive } & \multirow{2}{*}{ Pacing } & \multicolumn{2}{|c|}{ Running } \\
\hline & & & & & & Zigzags & Straight \\
\hline \multirow[t]{3}{*}{ Group 1} & 1 & $19.14 \pm 1.15$ & $36.46 \pm 1.41$ & $0.26 \pm 0.15$ & $21.64 \pm 1.21$ & - & $18.45 \pm 1.14$ \\
\hline & 2 & $24.22 \pm 1.26$ & $64.65 \pm 1.40$ & $0.26 \pm 0.15$ & $4.48 \pm 0.61$ & $0.09 \pm 0.09$ & $0.95 \pm 0.28$ \\
\hline & 3 & $30.09 \pm 1.35$ & $41.81 \pm 1.45$ & $0.69 \pm 0.24$ & $11.12 \pm 0.92$ & $0.17 \pm 0.12$ & $8.45 \pm 0.82$ \\
\hline \multirow[t]{3}{*}{3} & 1 & $18.27 \pm 2.27$ & $66.21 \pm 2.78$ & - & $9.31 \pm 1.71$ & - & $2.41 \pm 0.90$ \\
\hline & 2 & $31.72 \pm 2.74$ & $63.10 \pm 2.84$ & - & - & - & $0.34 \pm 0.34$ \\
\hline & 3 & $24.48 \pm 2.53$ & $57.59 \pm 2.91$ & $1.03 \pm 0.59$ & $1.03 \pm 0.59$ & - & $0.69 \pm 0.49$ \\
\hline \multirow[t]{3}{*}{4} & 1 & $6.90 \pm 1.49$ & $18.62 \pm 2.29$ & - & $43.79 \pm 2.92$ & - & $19.31 \pm 2.32$ \\
\hline & 2 & $11.38 \pm 1.87$ & $58.96 \pm 2.89$ & $0.69 \pm 0.49$ & $16.90 \pm 2.20$ & - & - \\
\hline & 3 & $14.14 \pm 2.05$ & $26.90 \pm 2.61$ & $1.03 \pm 0.59$ & $39.65 \pm 2.88$ & $0.34 \pm 0.34$ & $3.79 \pm 1.12$ \\
\hline \multirow[t]{3}{*}{5} & 1 & $31.72 \pm 2.74$ & $23.10 \pm 2.48$ & - & $4.83 \pm 1.26$ & - & $39.65 \pm 2.88$ \\
\hline & 2 & $36.90 \pm 2.83$ & $59.65 \pm 2.88$ & $0.34 \pm 0.34$ & - & - & $2.41 \pm 0.90$ \\
\hline & 3 & $47.93 \pm 2.94$ & $21.38 \pm 2.41$ & $0.34 \pm 0.34$ & $2.41 \pm 0.90$ & - & $26.90 \pm 2.61$ \\
\hline \multirow[t]{3}{*}{7} & 1 & $19.65 \pm 2.34$ & $37.93 \pm 2.85$ & $1.03 \pm 0.59$ & $28.62 \pm 2.66$ & - & $12.41 \pm 1.94$ \\
\hline & 2 & $16.90 \pm 2.20$ & $76.90 \pm 2.48$ & - & $1.03 \pm 0.59$ & $0.34 \pm 0.34$ & $1.03 \pm 0.59$ \\
\hline & 3 & $33.79 \pm 2.78$ & $61.38 \pm 2.86$ & $0.34 \pm 0.34$ & $1.38 \pm 0.69$ & $0.34 \pm 0.34$ & $2.41 \pm 0.90$ \\
\hline \multirow[t]{3}{*}{ Group 2} & 1 & $48.73 \pm 1.50$ & $21.96 \pm 1.25$ & $0.09 \pm 0.09$ & $1.09 \pm 0.31$ & $0.45 \pm 0.20$ & $25.77 \pm 1.32$ \\
\hline & 2 & $30.34 \pm 1.35$ & $42.32 \pm 1.45$ & $1.38 \pm 0.34$ & $0.08 \pm 0.08$ & - & $5.17 \pm 0.65$ \\
\hline & 3 & $34.22 \pm 1.39$ & $23.10 \pm 1.23$ & $0.34 \pm 0.17$ & $0.60 \pm 0.23$ & $0.43 \pm 0.19$ & $25.34 \pm 1.28$ \\
\hline \multirow[t]{3}{*}{1} & 1 & $48.27 \pm 2.94$ & $24.48 \pm 2.53$ & - & $2.07 \pm 0.84$ & $0.69 \pm 0.49$ & $24.48 \pm 2.53$ \\
\hline & 2 & $43.44 \pm 2.91$ & $30.00 \pm 2.69$ & $3.10 \pm 1.02$ & - & - & $4.14 \pm 1.17$ \\
\hline & 3 & $44.83 \pm 2.92$ & $22.76 \pm 2.47$ & $0.34 \pm 0.34$ & $1.03 \pm 0.34$ & $0.03 \pm 0.59$ & $29.31 \pm 2.68$ \\
\hline \multirow[t]{3}{*}{2} & 1 & $72.41 \pm 2.63$ & $13.79 \pm 2.03$ & - & $1.03 \pm 0.59$ & $0.69 \pm 0.49$ & $8.96 \pm 1.68$ \\
\hline & 2 & $38.62 \pm 2.86$ & $16.55 \pm 2.19$ & $0.34 \pm 0.34$ & - & - & $0.69 \pm 0.49$ \\
\hline & 3 & $45.86 \pm 2.93$ & $16.21 \pm 2.16$ & $0.34 \pm 0.34$ & - & - & - \\
\hline \multirow[t]{3}{*}{6} & 1 & $60.34 \pm 2.87$ & $32.76 \pm 2.76$ & $0.34 \pm 0.34$ & $0.34 \pm 0.34$ & - & $4.48 \pm 1.22$ \\
\hline & 2 & $23.79 \pm 2.50$ & $64.83 \pm 2.81$ & $1.03 \pm 0.59$ & - & - & - \\
\hline & 3 & $43.79 \pm 2.92$ & $52.07 \pm 2.94$ & $0.69 \pm 0.49$ & $0.34 \pm 0.34$ & $0.69 \pm 0.49$ & $0.69 \pm 0.49$ \\
\hline \multirow[t]{3}{*}{8} & 1 & $5.17 \pm 1.46$ & $15.52 \pm 2.38$ & - & $0.86 \pm 0.60$ & $0.43 \pm 0.43$ & $75.00 \pm 2.84$ \\
\hline & 2 & $15.52 \pm 2.13$ & $57.93 \pm 2.90$ & $1.03 \pm 0.59$ & $0.34 \pm 0.34$ & - & $15.86 \pm 2.15$ \\
\hline & 3 & $2.41 \pm 0.90$ & $1.38 \pm 0.67$ & - & $1.03 \pm 0.59$ & $0.69 \pm 0.49$ & $71.38 \pm 2.66$ \\
\hline
\end{tabular}

(-) Behaviours not registered during the tests.

sponses to spread trough a population (GRIFFIN \& EvANs 2003). The cultural transmission of the antipredator behaviours has been observed in several species of birds, such as ducks (KLOPFER 1957) and passerine birds (Lorenz 1952, CuRIO et al. 1978, VIETH et al. 1980). For ratites, birds that normally live in groups (PERRINS \& Middleton 1998), the cultural transmission of antipredator skills is probably very important. The enhancement of antipredator responses due to social training for greater rheas, meanwhile, has to be tested.

The positive effects of antipredator training is confirmed by the fact that the rheas avoided the novel objects much more time after it implementation than before. To avoid novel stimuli when reintroduced in the wild is a great advantage to the birds since it can increase their survival capabilities. Some birds, meanwhile, do not responded in this manner, increasing the numbers of approaching to the objects after the application of the antipredator training. Birds that occupy the bold region of the shy-bold continuum, like rhea one, are not good animals to be reintroduced. The probabilities of these rheas to be killed just after their release into the wild are big enough to not be tried. Birds with this kind of behavioural responses are better thrifty in environmental education programs of zoos. 
Once the investments in reintroduction programs are huge, to choose the best animals to release is of great importance. Personality assessments and cluster analysis are tools that can be used in this way. More refined tests, like Principal Components Analysis (PCA) and Discriminant Analysis, can also be used to help in the decisions of which animals are better to be trained and reintroduced and which animals are better to be used in captive reproduction and environmental education programs, but the number of individuals studied needs to be larger than the number of animals studied here.

It is important to evaluate the survival rates of the animals after the releasing into the nature. Only with this kind of study we can truly say if the antipredator training applied to the best individuals increased the survival of the animals and helped in the establishment of new viable population in the wild.

\section{ACKNOWLEDGEMENTS}

We would like to thank Dr. Andrea Griffin for helped us with the methodologies of the antipredator training used in this research; to BH Zoo for the consent to study their animals; to Ângela Bernadete Faggioli and the staff of Bird Section for their help and suggestions; Dr. Samantha Bremner for her help with the boldness score. This study was undertaken while Cristiano Schetini de Azevedo was in receipt of a postgraduate scholarship from CAPES (Coordenação de Aperfeiçoamento de Pessoal de Nível Superior). The research conducted in this article conforms with the animal care laws in Brazil and was approved by the Zoo's Ethical Committee.

\section{REFERENCES}

Bremner-Harrison, S.; P.A. Prodohk \& R.W. Elwood. 2004. Behavioural trait assessment as a release criterion: boldness predicts early death in a reintroduction programme of captive-bred swift fox, Vulpes velox. Animal Conservation, Cambridge, 7: 313-320.

Coleman, K. \& D.S. Wilson. 1998. Shyness and boldness in pumpkinseed sunfish: individual differences are contextspecific. Animal Behaviour, Nottingham, 56: 927-936.

Curio, E. 1988. Cultural transmission of enemy recognition by birds, p. 75-97. In: T.R. Zental \& B.G. Galef Jr. (Eds). Social learning: psychological and biological perspectives. New Jersey, Hilldalf, 368p.

Curio, E.; U. ERnst \& W. Vieth. 1978. The adaptative significance of avian mobbing. Zeitschrift fur Tierpsychologie, Moscow, 48: 184-202.

DANI, S. 1993. A ema Rhea americana. Belo Horizonte, Fundação Acangaú, 136p.

Del Hoyo, J.; A. Elliot \& J.A. Sargatal. 1992. A Handbook of the birds of the world. Barcelona, Lynx Editions, vol. 1, 696p.

GALEF, B.J. 1988. Imitation in animals: history, definition, and interpretation of data from the psychological laboratory, $\mathrm{p}$. 3-28. In: T.R. Zental \& B.G. Galef JR. (Eds). Social learning: psychological and biological perspectives. New Jersey, Hilldalf, 368p.

Greenberg, R. 1989. Neophobia, aversion to open space, and ecological plasticity in song and swamp sparrows. Canadian Journal of Zoology, Toronto, 67: 1194-1199.

Griffin, A.S. \& C.S. Evans. 2003. The role of differential reinforcement in predator avoidance learning. Behavioural Processes, Dijon, 61: 87-94.

Griffin, A.S.; C.S. Evans \& D.T. Blumstein. 2001. Learning specificity in acquired predator recognition. Animal Behaviour, Nottingham, 62: 577-589.

IUCN, 2004. The IUCN Red List of Threatened Species. Available in the World Wide Web at: http://www.redlist.org [accessed on 27/I/2004].

Kagan, J.; J.S. Reznick \& N. Snidman. 1988. Biological bases of childhood shyness. Science, Whashington, 240: 167-171.

Kelley, J.L.; J.P. Evans; I.W. Ramnarine \& A.E. Magurran. 2003. Back to school: can antipredatory behaviour in guppies be enhanced through social learning? Animal Behaviour, Nottingham, 65: 665-662.

Kleiman, D.G. 1996. Reintroduction programs, p. 297-305. In: D.G. Kleiman; M.E. Allen; K.V. Thompson \& S. LumpKin (Eds). Wild Mammals in Captivity. Chicago, University of Chicago Press, 656p.

KLOPFer, P.H. 1957. An experiment on emphatic learning in ducks. The American Naturalist, Chicago, 91: 61-63.

Lorenz, K. 1952. King's Solomon's Ring. New York, Thomas and Crowell Company, 216p.

LowE, S.E. \& J.W.S. BRADShaW. 2001. Ontogeny of individuality in the domestic cat in the home environment. Animal Behaviour, Nottingham, 61: 231-37.

Machado, A.B.M.; G.A.B. Fonseca; R.B. Machado; L.M.S. Aguiar \& L.V. Lins. 1998. Livro vermelho das espécies ameaçadas de extinção da fauna de Minas Gerais. Belo Horizonte, Fundação Biodiversitas, 605p.

Mather, J.A. \& R.C. Andersson. 1993. Personalities of octopuses (Octopus rubescens). Journal of Comparative Psychology, Washington, 107: 336-340.

Perrins, C.M. \& A.L.A. Middleton. 1998. The Encyclopaedia of Birds. New York, Facts of File, $16+63 p$.

SICK, H. 1997. Ornitologia Brasileira. Rio de Janeiro, Editora Nova Fronteira, 862p.

SNEDDON, L.U. 2003. The bold and the shy: individual differences in rainbow trout. Journal of Fish Biology, Oxford, 62: 971975.

Suboski, M.D.; S. Bain; A.E. Carty; L.M. McQuoid; M.I. Seelen \& M. Seifert. 1990. Alarm reaction in acquisition and social transmission of simulated-predator recognition by zebra danio fish (Brachydanio rerio). Journal of Comparative Psychology, Washington, 104: 101-112.

SVARTBERG, K. 2002. Shyness-boldness predicts performance in working dogs. Applied Animal Behaviour Science, Frederiksberg, 79: 157-174. 
Svartberg, K. \& B. Forkman. 2002. Personality traits in the domestic dog (Canis familiaris). Applied Animal Behaviour Science, Frederiksberg, 79: 133-155.

Verbeek, M.E.M.; P. de Goede; P.J. Drent \& P.R. WiepKema. 1999. Individual behavioural characteristics and dominance in aviary groups of great tits. Behaviour, Noordbroek, 136: 23-48.

Vieth, W.; E. Curio \& U. ERnst. 1980. The adaptative significance of avian mobbing. III. Cultural transmission of enemy recognition in blackbirds: cross-species tutoring and properties of learning. Animal Behaviour, Nottingham, 28: 1217-1229.

Wilson, D.S.; K. Coleman; A.B. Clark \& L. Biederman. 1993. Shybold continuum in pumpkinseed sunfish (Lepomis gibbosus): an ecological study of a psychological trait. Journal of Comparative Psychology, Washington, 107: 250-260.

Wilson, D.S.; A.B. Clark; K. Coleman \& T. Dearstyne. 1994. Shyness and boldness in humans and other animals. Trends in Ecology and Evolution, London, 9: 442-446.

Received in 15.III.2005; accepted in 03.II.2006. 